\title{
PENGARUH KUALITAS PELAYANAN DAN SASARAN KESELAMATAN PASIEN TERHADAP KEPUASAN PASIEN DI RUMAH SAKIT \\ Lidya Andriani S \\ lidyahartinisihombing@gmail.com
}

Keselamatan pasien (patient safety) adalah dasar dari pelayanan kesehatan yang baik. Keselamatan pasien juga menjadi salah satu indikator dalam menilai akreditas institusi pelayanan kesehatan, oleh karena itu keselamatan pasien sangat penting. Namun, jika ditinjau dari insiden keselamatan pasien, keselamatan pasien di berbagai tingkat pelayanan kesehatan masih buruk, baik secara global maupun nasional (Kusek, 2012) Perkembangan kesehatan bertujuan mewujudkan derajat kesehatan masyarakat setinggi-tingginya, sebagai pembangunan sumber daya manusia yang produktif secara sosial dan ekonomi (UU No 44/2009). Untuk mewujudkan tujuan tersebut diperlukan ketersediaan pelayanan kesehatan yang bermutu.

Hasil penelitian menunjukkan bahwa koefisien regresi variabel kualitas pelayanan (B1) adalah diketahui sebesar 0,110 yang menunjukkan besarnya pengaruh variabel kualitas pelayanan terhadap kepuasan pasien. Hasil koefisien regresi menunjukkan kualitas pelayanan pengaruh 0,110 terhadap kepuasan pasien, dimana pengaruh tersebut positif (searah). Itu koefisien regresi variabel target keselamatan pasien (B2) diketahui sebesar 0,551 yang menunjukkan pengaruh variabel target keselamatan pasien terhadap kepuasan pasien. Hasil regresi koefisien artinya tujuan keselamatan pasien berpengaruh sebesar 0,551 terhadap kepuasan pasien, dimana pengaruhnya positif (searah). Variabel kualitas pelayanan secara parsial signifikan terhadap Variabel kepuasan pasien dan target keselamatan pasien secara parsial signifikan terhadap pasien kepuasan. Hasil ini berarti bahwa tujuan keselamatan pasien merupakan variabel yang berpengaruh dominan terhadap kepuasan pasien. Nilai koefisien korelasi (r) sebesar 0,904. Ini menunjukkan sikap positif dan kuat hubungan antara variabel kualitas pelayanan dan tujuan keselamatan pasien dengan pasien kepuasan.

Kata Kunci: Keselamatan dan pelayanan pasien

\section{LATAR BELAKANG}

Keselamatan pasien merupakan hal yang vital dari sebuah rumah sakit. Menurut World Health Organization (WHO) (2018), keselamatan pasien adalah upaya untuk mencegah kesalahan dalam perawatan kesehatan. Perkembangan kesehatan bertujuan mewujudkan derajat kesehatan masyarakat setinggi-tingginya, sebagai pembangunan sumber daya manusia yang produktif secara sosial dan ekonomi (UU No 44/2009). Untuk mewujudkan tujuan tersebut diperlukan ketersediaan pelayanan kesehatan yang bermutu. Mutu layanan 
kesehatan dapat di definisikan sebagai derajat kesempurnaan pelayanan rumah sakit untuk memenuhi kebutuhan masyarakat akan pelayanan kesehatan yang sesuai standar profesi dan standar pelayanan dengan menggunakan sumber daya yang tersedia di rumah sakit secara wajar, efisien, dan efektif serta diberikan secara aman dan memuaskan sesuai dengan norma, etika, hukum, dan sosio budaya dengan memperhatikan keterbatasan dan kemampuan rumah sakit dan masyarakat. Ada tiga bentuk masalah yang terdapat dalam mutu layanan kesehatan yaitu; penggunaan layanan yang tidak optimal riset klinis sudah menghasilkan begitu banyak metode pengobatan yang terbukti efektif yang tidak dipergunakan secara luas. Penggunaan berlebihan juga menjadi masalah mutu karena pengobatan tertentu diberikan tanpa mengindahkan bukti bahwa pengobatan tersebut tidak efektif atau bahkan berbahaya (Sharon, 2017:66).

\section{Pengertian Kualitas Pelayanan}

1. Kualitas menurut American Society for quality control adalah keseluruhan dari ciri - ciri dan karakteristik dari suatu produk/jasa dalam hal kemampuannya untuk memenuhi kebutuhan kebutuhan yang telah ditentukan atau bersifat laten, dan dengan kata lain kualitas suatu produk/jasa adalah sejauh mana produk/jasa memenuhi spesifikasi-spesifikasinya. (Ratnasari, 2011:103-104)

2. Kualitas menurut ISO 9000 adalah degree to which a set of inherent characteristics fulfils implied or obligatory (derajat yang dicapai oleh karakteristik yang interen dalam memenuhi persyaratan) (Susanti, 2015:284)

3. Kualitas jasa adalah jika kenyataan lebih dari yang diharapkan, maka dapat dikatakan bermutu, sedangkan jika kenyataan kurang dari yang diharapkan, maka layanan dikatakan tidak bermutu. (Mastuti, 2011:107)

4. Mutu adalah tingkat kesempurnaan suatu produk atau jasa. Mutu adalah expertise atau keahlian dan keterikatan (commitment) yang selalu dicurahkan pada pekerjaan. Mutu adalah kegiatan tanpa salah dalam melakukan pekerjaan. (Pedoman mutu pelayanan rumah sakit, 1994:4)

5. Kualitas produk dan jasa kesehatan adalah keseluruhan gabungan karakteristik produk dan jasa dari pemasaran, rekayasa, pembuatan, dan pemeliharaan yang membuat produk dan jasa yang digunakan memenuhi harapan pelanggan. (Aditama, 2015:156)

6. Kualitas layanan kesehatan adalah derajat ketika layanan kesehatan bagi individu maupun populasi meningkatkan probabilitas hasil akhir 
kesehatan yang diinginkan dan konsisten dengan pengetahuan profesional saat ini. (Sharon, 2017:64)

7. Kualitas pelayanan Rumah sakit adalah derajat kesempurnaan pelayanan rumah sakit

untuk memenuhi kebutuhan masyarakat akan pelayanan kesehatan yang sesuai standar

profesi dan standar pelayanan dengan menggunakan sumber daya yang tesedia di rumah

sakit secara wajar, efisien, dan efektif serta diberikan secara aman dan memuaskan sesuai

dengan norma, etika, hukum, dan sosio budaya dengan memperhatikan keterbatasan dan

kemampuan rumah sakit dan masyarakat. (Pedoman mutu pelayanan rumah sakit, 1994:4)

\section{Model Kualitas Pelayanan}

Parasuraman, Zeithaml, dan Berry mengembangkan model kualitas jasa yang dinamakan SERVQUAL. Model ini berkaitan erat dengan model kepuasan pelanggan yang sebagian besar didasarkan pada pendekatan diskonfirmasi. Model kualitas pelayanan (service quality) secara umum meliputi analisis terhadap lima gap yang berpengaruh terhadap kualitas jasa. Isu keselamatan pasien melahirkan paradigma baru tentang mutu pelayanan. Mutu pelayanan yang baik saja tidak cukup berarti bagi pasien tanpa memperhatikan bagaimana derajat unsur resiko dan keselamatan yang diterima oleh pasien. Tinggi rendahnya mutu sebanding dengan tingkat ketersediaan fasilitas pelayanan, untuk mencapai keseimbangan terbaik antara risiko dan manfaat keselamatan yang diterima oleh pasien.

\section{METODE}

Rancangan penugasan kajian ini menggunakan buku teks, buku referensi, jurnal print, Thesis, disertasi,e-journal (10 tahun terakhir) dengan menganalisa, eksplorasi dan kajian bebas. Sesuai dengan perumusan masalah dan tujuan penelitian yang hendak dicapai, maka penelitian ini menggunakan jenis penelitian explanatory research.

\section{HASIL DAN PEMBAHASAN}

Hasil analisis regresi linier berganda, menunjukkan bahwa variabel kualitas pelayanan dan sasaran keselamatan pasien berpengaruh secara simultan terhadap kepuasan pasien rawat inap di rumah sakit Prima Husada Malang. Hal ini berarti lima variabel kualitas pelayanan dan enam variabel sasaran keselamatan pasien secara bersama-sama (simultan) mempengaruhi kepuasan pasien. Hasil tersebut sesuai dengan penelitian yang dilakukan oleh Dolly (2015). Variabel kualitas yang digunakan sama dengan penelitian yang dilakukan dirumah sakit Prima Husada Malang. Pada 
penelitian tersebut variabel kualitas yang diteliti adalah tangibility, reliability, responsiveness, assurance, emphaty dan affordability. Menurut penelitian Dolly (2015), bahwa lima variabel kualitas pelayanan yang berpengaruh terhadap kepuasan pasien yaitu responsiveness, assurance, komunikasi, dan disiplin. Penelitian tersebut dilakukan di beberapa rumah sakit di negara berkembang. Penelitian yang dilakukan di RS Prima Husada berdasarkan variabel konsep yang disusun oleh Dolly (2015). Variabel ini merupakan kompilasi dari beberapa variabel-variabel kualitas pelayanan dari berbagai penelitian, sehingga hasil dari penelitian ini mendukung hasil penelitian-penelitian sebelumnya.

Hasil penelitian Anton

mempunyai kesesuaian dengan penelitian di RS Prima Husada yaitu, di peroleh p value $0,000(\alpha<0,05)$ untuk perhatian identifikasi pasien, komunikasi saat operan, pengendalian cairan peka, akurasi ketepatan pemberian obat, dan kebersihan mencuci tangan. Berdasarkan hasil analisis diketahui jika responden memberikan penilaian yang positif terhadap tindakan yang dilakukan oleh tenaga medis dan non medis di RS Prima Husada terkait dengan keselamatan pasien. Hasil penelitian tersebut mendukung penelitian yang dilakukan oleh Anton (2013) yang menemukan bahwa terdapat hubungan antara Keselamatan pasien dengan kepuasan pelanggan di ruang rawat inap RSJ Grhasia PEMDA DIY.

Penerapan keselamatan pasien dilaksanakan dengan baik maka pelayanan yang mengutamakan keselamatan dan kualitas yang optimal akan memberikan dampak yang luas. Terutama bagi masyarakat akan mendapatkan pelayanan yang lebih berkualitas, aman dan memenuhi harapan mereka. Bagi rumah sakit menjadi nilai tambah untuk pencapaian pelayanan yang berstandar nasional dan internasional. Pelayanan yang aman dan kualitas juga diharapkan dapat meningkatkan kepercayaan publik kepada rumah sakit. Bagi tenaga kesehatan dapat menumbuhkan nilai-nilai baru khususnya arti penting penerapan keselamatan pasien dalam setiap aktivitas pelayanan yang diberikan (Agency for Healthcare Research and Quality/AHRQ, 2015). Berdasarkan hal tersebut penulis berpendapat teknik pengawasan seorang kepala ruang mempunyai tanggung jawab yang besar dalam organisasi dan menentukan pecapaian tujuan organisasi dalam hal ini untuk meningkatkan keselamatan pasien dan mencegah terjadinya insiden keselamatan pasien.

Berdasarkan hasil penelitian dan teori diatas dapat disimpulkan bahwa pihak manajemen rumah sakit perlu melakukan mapping dan upaya peningkatan kualifikasi sumber daya manusia (perawat), selain sebagai upaya meningkatkan pemahaman secara kontekstual, juga diharapkan dapat 
meningkatkan kinerja yang lebih optimal terutama dalam implementasi sasaran keselamatan pasien. Hal tersebut juga mendukung upaya yang dilakukan oleh pemerintah tentang penentuan jenjang karis perawat yang telah diatur dalam Peraturan Menteri Kesehatan Ri no.40 Tentang Pengembangan jenjang karir perawat (KEMENKES RI, 2017c).

\section{KESIMPULAN}

Berdasarkan hasil penelitian dan analisis maka dapat dikemukakan beberapa kesimpulan sebagai berikut:

1) Koefisien regresi variabel kualitas pelayanan (B1) diketahui sebesar 0,110 yang menunjukkan besarnya pengaruh variabel kualitas pelayanan terhadap kepuasan pasien. Hasil koefisien regresi tersebut bermakna bahwa kualitas pelayanan memiliki pengaruh sebesar 0,110 terhadap kepuasan pasien, dimana pengaruhnya positif (searah).

2) Koefisien regresi variabel sasaran keselamatan pasien (B2) diketahui sebesar 0,551 yang menunjukkan besarnya pengaruh variabel sasaran keselamatan pasien terhadap kepuasan pasien. Hasil koefisien regresi tersebut bermakna bahwa sasaran keselamatan pasien memiliki pengaruh sebesar 0,551 terhadap kepuasan pasien, dimana pengaruhnya positif (searah).

3) Variabel kualitas pelayanan secara parsial berpengaruh signifikan terhadap kepuasan pasien dan variabel sasaran keselamatan pasien secara parsial berpengaruh signifikan terhadap kepuasan pasien.

4) Hipotesis yang menyatakan kualitas pelayanan (X1) dan sasaran keselamatan pasien (X2) secara simultan berpengaruh signifikan terhadap kepuasan pasien dalam penelitian ini dapat diterima.

5) Nilai koefisien beta yang distandarisasi variabel sasaran keselamatan pasien lebih besar dibandingkan dengan nilai koefisien beta yang distandarisasi variabel kualitas pelayanan. Hasil tersebut bermakna sasaran keselamatan pasien merupakan variabel yang berpengaruh dominan terhadap kepuasan pasien.

6) nilai koefisien korelasi (r) sebesar 0,904. Hal ini menunjukkan adanya hubungan positif dan kuat antara variabel kualitas pelayanan dan sasaran keselamatan pasien dengan kepuasan pasien. 


\section{DAFTAR PUSTAKA}

Sriningsih, dkk. (2020). Pengetahuan penerapan keselamatan pasien (Patient Safety) pada petugas kesehatan. Jurnal Kesehatan, 9 (1)

Sakinah, dkk. (2017). Analisis sasaran keselamatan pasien dilihat dari aspek pelaksanaan identifikasi pasien dan keamanan obat di RS kepresidenan RSPAD gatot soebroto jakarta. Jurnal kesehatan masyarakat, 5 (4), 145-152

Ulumiyah, dkk. (2018). Meningkatkan mutu pelayanan kesehatan dengan penerapan upaya keselamatan pasien di puskesmas. Jurnal Administrasi Kesehatan Indonesia, 6 (2), 149-155 Supartiningsih Solichah. 2017. Kualitas pelayanan kepuasan pasien rumah sakit: kasus pada pasien rawat jalan. Jurnal medicoeticolegal dan manajemen rumah sakit, 6 (1), 10-14 Surahmat, dkk. (2019). Hubungan supervisi dengan implementasi sasaran keselamatan pasien di rumah sakit muhammadiyah palembang. Seminar Nasional Keperawatan "Tren Perawatan Paliatif sebagai Peluang Praktik Keperawatan Mandiri”, 173-178

Neri, dkk. (2018). Analisis pelaksanaan sasaran keselamatan pasien di rawat inap rumah sakit umum daerah padang pariaman. Jurnal kesehatan andalas, 7 (4), 48-55

Harfikah, dkk. (2017). Pengaruh kualitas pelayanan dan fasilitas terhadap kepuasan pasien pada rumah sakit umum kabupaten aceh barat daya. Jurnal balance, 14 (1), 44-56

Surahmat, dkk. (2019). Hubungan karakteristik perawat terhadap pelaksanaan sasaran keselamatan pasien pasca akreditasi rumah sakit "X" di kota palembang tahun 2018. Jurnal ilmiah universitas batanghari jambi, 19 (1), 1-10

Suarjana MGAA. (2015). Pengaruh kualitas pelayanan terhadap kepuasan dalam rangka menciptakan loyalitas pasien pada rumah sakit umum daerah sanjiwani kabupaten gianyar. Jurnal bisnis dan kewirausahaan, 11 (1), 10-22

Pambudi, dkk. (2018). Faktor-faktor yang mempengaruhi perawat dalam penerapan 6 SKP (sasaran keselamatan pasien) pada akreditasi JCI (joint commission international) di ruang rawat inap rumah sakit panti waluya malang. Jurnal nursing news, 3 (1), 729-747

Manik Sudarmin. (2016). Pengaruh kualitas pelayanan terhadap kepuasan pasien pada rumah sakit thursina di duri: Hal 80-93

Setiyani dwi, dkk. (2016). Implementasi sasaran keselamatan pasien di ruang rawat inap RSU kabupaten tanggerang. JKFT, 2, 59-69

Hasanah, dkk. (2020). Pengaruh kualitas pelayanan dan fasilitas terhadap kepuasan pasien.

JIAGABI, 9 (2), 185-191 
Zakaria MF. (2017). Pengaruh kualitas pelayanan dan sasaran keselamatan pasien terhadap kepuasan pasien rumah sakit prima husada malang. JIMMU, 2 (2), 98-106

Simamora, R. H. (2018). Buku ajar keselamatan pasien melalui timbang terima pasien berbasis komunikasi efektif: SBAR. Medan: USUpress.

Simamora, R. H. (2020). Learning of Patient Identification in Patient Safety Programs Through Clinical Preceptor Models. Medico Legal Update, 20(3), 553-556. 